\title{
Methodological basis of internal control in the costs management system of enterprises
}

\author{
Guzaliya Klychova $^{1}$, Alsou Zakirova ${ }^{1,{ }^{*},}$ Amina Khusainova $^{2}$, Ekaterina Markovina ${ }^{3}$, Elena \\ Zaharova $^{3}$ \\ ${ }^{1}$ Kazan State Agrarian University, 65, Karl Marx str., 420015, Kazan, Russia \\ ${ }^{2}$ Interregional branch of the Federal State Institution «Center for Ensuring the Activities of the \\ Treasury of Russia», 61, k. 1, Karl Marx str., 420015, Kazan, Russia \\ ${ }^{3}$ Izhevsk State Agricultural Academy, 11, Studencheskaya str., 426069, Izhevsk, Russia
}

\begin{abstract}
In modern conditions the functioning of enterprises is influenced by a number of factors, which include a tough competitive environment, limited material resources necessary to carry out production activities, the economic crisis caused by the pandemic COVID-19. The main tasks, which should be solved to increase the effectiveness of the company's activity, are tasks, connected with minimization of expenses for production, works and services. To solve these tasks, it is necessary to implement effective and rational internal control. The article's purpose consists of studying of organizational aspects and development of directions of improvement of methodical provision of internal control of production costs and product costing. As one of the tools of internal control it is recommended to use developed working documents of internal control. These documents make it possible to carry out effective planning of internal control; to evaluate effectiveness of internal control and accounting systems, to systematize information received during inspection of primary accounting and observation of norms of consumption of material assets during production; to generalize results of inspection and reflection of violations and mistakes revealed during internal control.
\end{abstract}

\section{Introduction}

In modern conditions any commercial enterprise should strive to improve the efficiency of production activities through the introduction of innovative production technologies; rational use of material, financial and labor resources; improvement of management system functions, including internal control [1,2].

Internal control is the basis for the adoption of effective management decisions by the subject of management. Internal control involves:

- verification of compliance with legal requirements, accurate and complete documentation of business transactions, timely reporting;

- fulfillment of control procedures in order to orderly and efficiently carry out production activities;

\footnotetext{
*Corresponding author: zakirovaar@mail.ru
} 
- implementation of a comprehensive assessment of the results of the enterprise as a whole and its structural divisions;

- providing the necessary information to the management of the enterprise [3-6].

The internal control system performs the following tasks:

- the object of control and the factors that influence it are systematically and systematically checked;

- to assess the achievement of the strategic and tactical goals of the enterprise, the planned and actual values of the indicators characterizing the production activity of the enterprise are compared [7];

- the results of production and financial activities of the enterprise are predicted [8];

- the necessity of carrying out corrective actions on the control object is substantiated and methods are determined that can be used during the implementation of such actions.

- reveals the reserves for increasing the efficiency of production activities [9];

- based on the information and analytical support available at the enterprise,

- on the basis of the information-analytical support available at the enterprise, recommendations for improving the system of accounting for production costs are developed [10].

The information received by results of internal control and given to managers of the enterprise should be objective. Consequently, the bodies that carry out control procedures should be independent of the business units they audit and should report and provide reports on the results of the audit only to those persons who initiated the audit, such as the management of the enterprise or its owners [11-13].

The importance of internal control lies in the fact that the management bodies of an enterprise can effectively control the activities of the structural units responsible for the safety, movement and accounting of resources used in production activities [14-16]. According to the results of the control actions, the perspective directions of development of the system of costs management can be worked out. Besides internal controllers carry out information and consulting functions in relation to those subdivisions that are connected with implementation of production activity [17-19].

When determining the strategy of internal control, which is the basis for the methodological support of inspection, the peculiarities of production, financial and economic activities of each business entity are taken into account.

Internal control of production costs implies control activities in the following stages:

Stage 1 - the system of accounting and internal control of costs of production, works and services is assessed;

Stage 2 - internal control of costs of production, works and services is planned (goals, objectives, objects, subjects, executors, methods and ways of control are defined);

Stage 3 - gathering and systematization of information for implementing control procedures;

Stage 4 - control procedures are performed including:

- verification of primary accounting,

- Checking the organization of analytical and synthetic cost accounting,

- check the organization of analytical, synthetic cost accounting, checking the calculation of the cost of production;

Stage 5 - violations, shortcomings and deviations of actual cost values from the planned or regulatory, their causes, the perpetrators are identified;

Stage 6 - information is provided, on the basis of which substantiated and management decisions are made on the results of internal control over production costs;

Stage 7 - implementation of the taken managerial decisions [20, 21].

Internal control of the enterprise is aimed at fulfilling plans and the successful implementation of the enterprise development strategy (Fig. 1). 


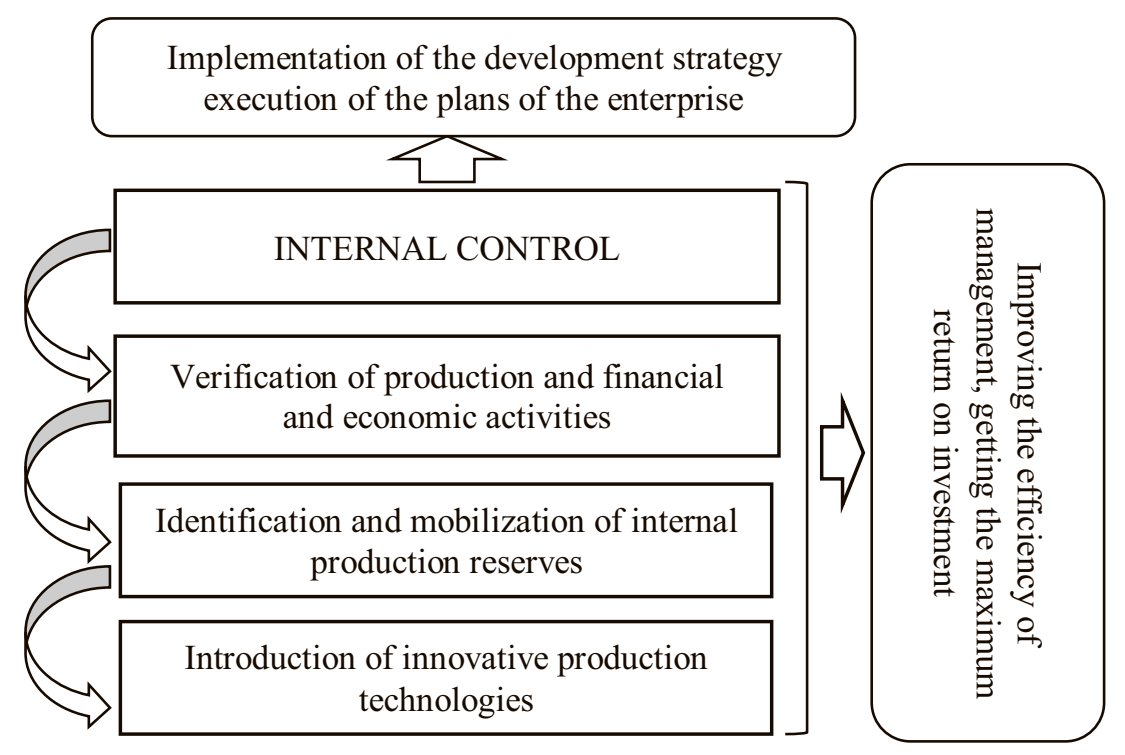

Fig. 1. Target orientation of internal control.

Under internal control, financial and production activities are comprehensively and systematically checked, internal production reserves are identified and mobilized, and innovative production technologies are introduced.

When organizing internal control, functional responsibilities are distributed between various departments, local regulations governing the verification process are developed, internal document flow is organized,

\section{Materials and Methods}

In the process of internal control of production costs, it is checked whether the procedure for cost accounting in force at the enterprise meets the requirements of normative and legislative acts; whether operations on cost accounting are reflected in a timely, accurate and full manner; whether errors and violations are prevented. As a result of the control procedures performed, the efficiency of cost accounting increases; the safety of the assets of the economic entity is ensured $[22,23]$.

In the process of achieving the goal of internal control of production costs the following tasks are solved:

- determines the actual state of costs at the time of the audit;

- the state and behavior of costs are predicted;

- the state and behavior of costs, in which they could provide the optimal and sufficient results of activity, are determined;

- timely prevention of occurrence of deviations from planned and standard indicators, places and reasons of their occurrence are defined;

- information on costs is accumulated, transferred, processed;

- steady state of costs is provided;

- the correctness of cost classification is checked;

- feasibility and correctness of implementation of business operations is checked;

- the reliability of accounting data is checked;

- the actual and targeted use of material resources is checked;

- production activities are audited to identify deviations and their causes;

- the completeness and timeliness of the reflection in the accounting of business 
operations related to the production of products, works and services [24-26] is checked.

The reliability of financial statements containing information on production costs is verified in the following ways:

- it is assessed whether the accounting policy in terms of production cost accounting complies with the requirements of regulatory acts;

- it is checked, whether the procedure of cost accounting accepted in the accounting policy is observed in practical activity of the enterprise;

- the composition and content of financial statements, the procedure for their preparation and presentation are checked;

- comparability, reliability, relevance and completeness of the information contained in the financial statements are checked;

- assessment of whether the information on production activities contained in the financial statements is reliable and its influence on stakeholders' evaluation and decisionmaking.

Procedures of internal control of accounting for production costs and calculation of the cost of production consist in checking the following provisions (Fig. 2)

\begin{tabular}{|c|c|c|} 
Control over the accounting of production costs and calculation of the cost of \\
production
\end{tabular}

Fig. 2. Procedures of internal control of manufacturing cost accounting and product costing. 
In the process of internal control of the cost of production the following methods of control are applied:

1. Documentary check is a method of control, which assesses the accuracy of accounting, drawing up and filling out forms of accounting (financial) documentation and reporting;

2. Testing is a method of control, with the help of which the state of internal control and organization of accounting at the enterprise is assessed on the basis of gathering reliable and sufficient evidence;

3. Normative inspection implies establishing the conformity of performed operations to the current legislation, checking the availability of documents and other conditions that confirm the validity and legality of individual business operations in accounting for production costs;

4. Formal inspection checks availability of documents registering the fact of operations, filling in of all requisites. defects in execution of documents are detected, authenticity of signatures of officials is verified;

5. Logical verification - a method of control, which compares the data on the operations of cost accounting, contained in the documents, with the various circumstances and phenomena that confirm the very possibility of its committing;

6. Tracing - a method of control, which involves checking the individual primary documents on accounting for costs of production, their subsequent reflection in the registers of accounting, determining the final correspondence of accounts, confirming the correctness of the reflection in the accounting of the relevant business operations;

7. Arithmetic check - a method that determines the accuracy of calculations made in the documents. With the help of this method the signs of theft of material assets in the course of production activities are identified;

8. Confirmation is a method of control, with the help of which information about the objectivity of recording in the accounting of business operations carried out and the reality of the balances in the accounts of production costs is obtained;

9. Inventory is a method of control, which is used to verify the conformity of the actual availability of tangible assets used in the production of products in kind to the accounting data, as well as to find out their safety in the organization;

10. Control launch of raw materials into production - using this method, the controller checks whether the current consumption rates of raw materials and materials used in the manufacture of products are reliable at the enterprise. The method makes it possible to identify facts when outdated norms are applied, which leads to the formation of unaccounted for surpluses in the divisions and in the warehouses of the enterprise;

11. Cross check - using this method, different documents or several copies of the same document are compared, which are located in different divisions of an economic entity or in counterparty organizations;

12. Expert estimation is a method used to evaluate the validity of material costs standards applied at an enterprise and the actual volume and quality of work performed, and to check whether enterprise technological modes are observed,

13. Analytical inspection - a method of control involving the analysis of production costs, comparison of actual data with forecasts, similar data of past periods, indicators of similar enterprises, industry average indicators; study of unexpected deviations; analysis of the effect of unforeseen factors; evaluation of the results of analysis in light of information received from others;

14. Checking of accounting registers - with the help of this method the information contained in the registers of synthetic and analytical accounting is compared with the information contained in the primary documents. Using this method of control, the auditor identifies false entries, which conceal embezzlement and abuse. 


\section{Results}

At the planning stage of internal control, the head of the working group develops a program (Table 1), which includes the following indicators:

- areas of internal control;

- normative and information base of the check;

- the schedule and composition of the working group of internal control;

- the nature of the audit, which depends on the scope of the company's activities;

- control procedures that are used to gather evidence in the verification process.

Table 1. Internal Control Working Document (ICWD) «Program of internal control of production costs».

\begin{tabular}{|c|c|c|c|c|c|c|}
\hline 兽 & 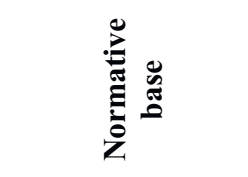 & 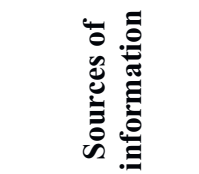 & & 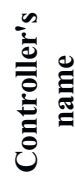 & 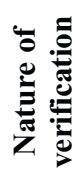 & 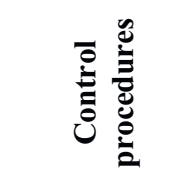 \\
\hline $\begin{array}{l}\text { 1. Assessment } \\
\text { of the } \\
\text { accounting } \\
\text { and internal } \\
\text { control } \\
\text { system }\end{array}$ & $\begin{array}{l}\text { Federal Law «On } \\
\text { Accounting», } \\
\text { Accounting } \\
\text { Regulation 10/99 } \\
\text { «Expenses of the } \\
\text { organization» }\end{array}$ & $\begin{array}{l}\text { Accounting } \\
\text { policy, } \\
\text { synthetic and } \\
\text { analytical } \\
\text { accounting } \\
\text { registers, } \\
\text { workflow } \\
\text { schedule }\end{array}$ & 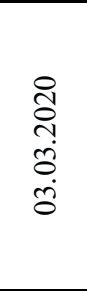 & 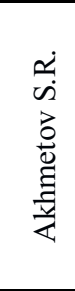 & 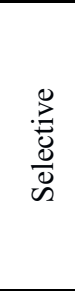 & $\begin{array}{l}\text { Testing, } \\
\text { documentary } \\
\text { verification }\end{array}$ \\
\hline $\begin{array}{l}\text { 2. Checking } \\
\text { the primary } \\
\text { accounting of } \\
\text { production } \\
\text { costs }\end{array}$ & $\begin{array}{l}\text { Federal Law «On } \\
\text { Accounting»; } \\
\text { Accounting } \\
\text { Regulation 10/99 } \\
\text { «Expenses of the } \\
\text { organization»; } \\
\text { Industry for } \\
\text { guidelines for } \\
\text { cost accounting } \\
\text { and product } \\
\text { costing }\end{array}$ & $\begin{array}{l}\text { Accounting } \\
\text { policy of the } \\
\text { enterprise, } \\
\text { primary } \\
\text { documents for } \\
\text { accounting for } \\
\text { production } \\
\text { costs, } \\
\text { workflow } \\
\text { schedule }\end{array}$ & 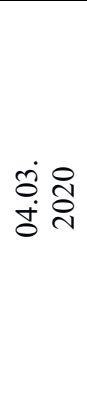 & 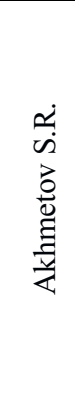 & $\begin{array}{l}\sum_{0}^{0} \\
\frac{0}{0} \\
\ddot{n}\end{array}$ & $\begin{array}{l}\text { Normative } \\
\text { verification, } \\
\text { formal } \\
\text { verification, } \\
\text { logical } \\
\text { verification }\end{array}$ \\
\hline $\begin{array}{l}\text { 3. Verification } \\
\text { of synthetic } \\
\text { and analytical } \\
\text { accounting of } \\
\text { production } \\
\text { costs }\end{array}$ & $\begin{array}{l}\text { Accounting } \\
\text { Regulation 10/99 } \\
\text { «Expenses of the } \\
\text { organization» } \\
\text { Methodical } \\
\text { instructions on } \\
\text { the inventory of } \\
\text { property and } \\
\text { financial } \\
\text { liabilities. Order } \\
\text { of the Ministry of } \\
\text { Finance of the } \\
\text { Russian } \\
\text { Federation of } \\
13.06 .1995 \text { г. № } \\
49\end{array}$ & $\begin{array}{l}\text { Synthetic and } \\
\text { analytical } \\
\text { accounting } \\
\text { registers, } \\
\text { General } \\
\text { ledger, } \\
\text { working chart } \\
\text { of accounts of } \\
\text { the } \\
\text { organization }\end{array}$ & 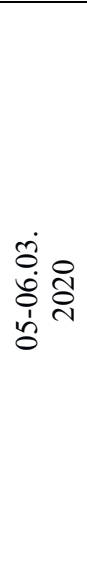 & 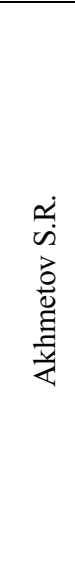 & $\begin{array}{l}\sum_{0}^{0} \\
\frac{0}{0} \\
\tilde{n}\end{array}$ & $\begin{array}{l}\text { Tracking, } \\
\text { arithmetic } \\
\text { checking, } \\
\text { confirmation, } \\
\text { checking of } \\
\text { synthetic and } \\
\text { analytical } \\
\text { accounting } \\
\text { registers }\end{array}$ \\
\hline
\end{tabular}




\begin{tabular}{|c|c|c|c|c|c|c|}
\hline $\begin{array}{l}\text { 4. Checking } \\
\text { the feasibility } \\
\text { of production } \\
\text { costs }\end{array}$ & $\begin{array}{l}\text { Federal Law «On } \\
\text { Accounting»; } \\
\text { Accounting } \\
\text { Regulation 10/99 } \\
\text { «Expenses of the } \\
\text { organization»; } \\
\text { Industry guidelines for } \\
\text { cost accounting } \\
\text { and product } \\
\text { costing }\end{array}$ & $\begin{array}{l}\text { Accounting } \\
\text { policy of the } \\
\text { enterprise, } \\
\text { primary } \\
\text { documents for } \\
\text { accounting for } \\
\text { production } \\
\text { costs, } \\
\text { accounting } \\
\text { registers, } \\
\text { business plan, } \\
\text { estimates }\end{array}$ & ல̊유 & 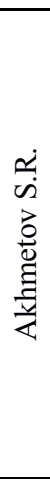 & $\frac{0}{0}$ & $\begin{array}{l}\text { Inventory, } \\
\text { control } \\
\text { launch of } \\
\text { raw materials } \\
\text { and materials } \\
\text { into } \\
\text { production, } \\
\text { arithmetic } \\
\text { verification; } \\
\text { expert } \\
\text { judgment, } \\
\text { regulatory } \\
\text { review }\end{array}$ \\
\hline $\begin{array}{l}\text { 5. Checking } \\
\text { the validity of } \\
\text { the methods } \\
\text { used at the } \\
\text { enterprise for } \\
\text { accounting for } \\
\text { costs and } \\
\text { calculating } \\
\text { the cost of } \\
\text { production }\end{array}$ & $\begin{array}{l}\text { Accounting } \\
\text { Regulation 10/99 } \\
\text { «Expenses of the } \\
\text { organization»; } \\
\text { Industry } \\
\text { guidelines for } \\
\text { cost accounting } \\
\text { and product } \\
\text { costing }\end{array}$ & $\begin{array}{l}\text { Accounting } \\
\text { policy of the } \\
\text { enterprise, } \\
\text { primary } \\
\text { documents for } \\
\text { accounting for } \\
\text { production } \\
\text { costs, } \\
\text { accounting } \\
\text { registers, } \\
\text { business plan, } \\
\text { estimates }\end{array}$ & లి & 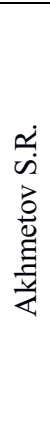 & $\frac{\stackrel{0}{0}}{\stackrel{0}{0}}$ & $\begin{array}{l}\text { Arithmetic } \\
\text { check, } \\
\text { counter } \\
\text { check }\end{array}$ \\
\hline $\begin{array}{l}\text { 6. Checking } \\
\text { itemized cost } \\
\text { accounting }\end{array}$ & $\begin{array}{l}\text { Industry } \\
\text { guidelines for } \\
\text { cost accounting } \\
\text { and product } \\
\text { costing }\end{array}$ & $\begin{array}{l}\text { Accounting } \\
\text { policy of the } \\
\text { enterprise, } \\
\text { primary } \\
\text { documents for } \\
\text { accounting for } \\
\text { production } \\
\text { costs, } \\
\text { accounting } \\
\text { registers }\end{array}$ & 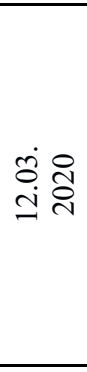 & 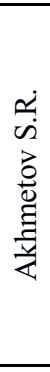 & $\begin{array}{l}\stackrel{0}{0} \\
\frac{0}{\omega} \\
\infty\end{array}$ & $\begin{array}{l}\text { Arithmetic } \\
\text { check, } \\
\text { counter } \\
\text { check }\end{array}$ \\
\hline $\begin{array}{l}\text { 7. Evaluation } \\
\text { of the results } \\
\text { of the } \\
\text { inventory of } \\
\text { work in } \\
\text { progress }\end{array}$ & $\begin{array}{l}\text { Methodical } \\
\text { instructions on } \\
\text { the inventory of } \\
\text { property and } \\
\text { financial } \\
\text { liabilities. Order } \\
\text { of the Ministry of } \\
\text { Finance of the } \\
\text { Russian } \\
\text { Federation of } \\
\begin{array}{l}13.06 .1995 \text { г. № } \\
49\end{array}\end{array}$ & $\begin{array}{l}\text { Inventory } \\
\text { lists, collation } \\
\text { statements, } \\
\text { Inventory plan } \\
\text { of property } \\
\text { and liabilities }\end{array}$ & 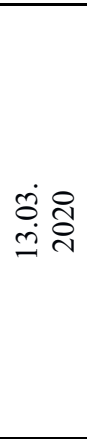 & 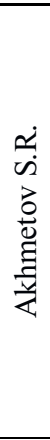 & $\begin{array}{l}\bar{T} \\
\stackrel{\bar{D}}{\circ}\end{array}$ & $\begin{array}{l}\text { Inventory, } \\
\text { arithmetic } \\
\text { checking, } \\
\text { tracking, } \\
\text { inspection }\end{array}$ \\
\hline $\begin{array}{l}\text { 8. Analysis of } \\
\text { the costs of } \\
\text { production }\end{array}$ & $\begin{array}{l}\text { Accounting } \\
\text { Regulation 10/99 } \\
\text { «Expenses of the } \\
\text { organization»; } \\
\text { Industry } \\
\text { guidelines for } \\
\text { cost accounting } \\
\text { and product } \\
\text { costing }\end{array}$ & $\begin{array}{l}\text { Synthetic and } \\
\text { analytical } \\
\text { accounting } \\
\text { registers, } \\
\text { General } \\
\text { ledger, } \\
\text { accounting } \\
\text { (financial) } \\
\text { statements }\end{array}$ & 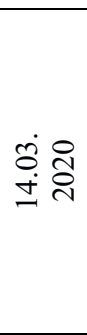 & 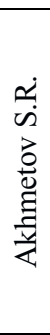 & $\begin{array}{l}\bar{F} \\
\bar{D} \\
\ddot{n}\end{array}$ & $\begin{array}{l}\text { Analytical } \\
\text { procedures, } \\
\text { arithmetic } \\
\text { verification }\end{array}$ \\
\hline
\end{tabular}


This program is a detailed instruction, on the basis of which the auditors carry out control measures in the course of the production costs audit.

One of the key stages of internal control of production costs is the evaluation of the accounting system and internal controls. The main method to evaluate the accounting and internal control system is testing.

We suggest using working papers of internal control «Test of assessment of accounting system for production costs» (Table 2) and «Test of assessment of internal control system for production costs» (Table 3 ) for conducting effective testing.

Table 2. ICWD «Test of assessment of the accounting system of costs of production».

\begin{tabular}{|c|c|c|c|c|}
\hline \multirow{2}{*}{ Questions } & \multicolumn{3}{|c|}{ Answer options } & \multirow{2}{*}{ Notes } \\
\hline & Yes & No & Partially & \\
\hline $\begin{array}{l}\text { 1. Are production costs } \\
\text { classified by items and } \\
\text { elements? }\end{array}$ & + & & & $\begin{array}{l}\text { Costs are classified by items and } \\
\text { elements in accordance with the } \\
\text { requirements of regulatory acts }\end{array}$ \\
\hline $\begin{array}{l}\text { 2. Does the accounting } \\
\text { policy in terms of } \\
\text { accounting for production } \\
\text { costs comply with the } \\
\text { requirements of regulatory } \\
\text { acts? }\end{array}$ & + & & & $\begin{array}{l}\text { The accounting policy defines a } \\
\text { system of cost accounting } \\
\text { accounts for production; specifies } \\
\text { the method of accounting for } \\
\text { production costs, the method of } \\
\text { distribution of general production } \\
\text { and general business expenses, } \\
\text { and the method of assessment of } \\
\text { work in progress. }\end{array}$ \\
\hline $\begin{array}{l}\text { 3. Is the cost accounting } \\
\text { procedure adopted in the } \\
\text { accounting policy complied } \\
\text { with in the practical } \\
\text { activities of the economic } \\
\text { services of the enterprise? }\end{array}$ & + & & & $\begin{array}{l}\text { The procedure of cost accounting } \\
\text { adopted in the accounting policy } \\
\text { is applied in the practical work of } \\
\text { the company's economic services. }\end{array}$ \\
\hline $\begin{array}{l}\text { 4. Is the cost of production } \\
\text { accounting differentiated by } \\
\text { reporting periods? }\end{array}$ & + & & & \begin{tabular}{llr} 
Production & \multicolumn{2}{c}{ costs } \\
differentiated & by are \\
periods. & &
\end{tabular} \\
\hline $\begin{array}{l}\text { 5. Does the method of } \\
\text { accounting for production } \\
\text { costs and calculating the } \\
\text { cost of production } \\
\text { correspond to the } \\
\text { production and } \\
\text { technological features of the } \\
\text { enterprise? }\end{array}$ & + & & & $\begin{array}{l}\text { The method of accounting for } \\
\text { production and calculating the } \\
\text { cost of production corresponds to } \\
\text { the specifics of production. }\end{array}$ \\
\hline $\begin{array}{l}\text { 6. Are the peculiarities of } \\
\text { the production activities of } \\
\text { the enterprise taken into } \\
\text { account in determining the } \\
\text { objects of cost accounting, } \\
\text { the objects of calculation } \\
\text { and calculation units? }\end{array}$ & + & & & $\begin{array}{l}\text { When determining the objects of } \\
\text { cost accounting, objects of } \\
\text { calculation and calculation units, } \\
\text { the specifics of the production } \\
\text { activities of the enterprise are } \\
\text { taken into account. }\end{array}$ \\
\hline $\begin{array}{l}7 . \text { Is the method of } \\
\text { evaluation of material } \\
\text { resources, which are spent } \\
\text { on the production of } \\
\text { products, established in the } \\
\text { accounting policy, } \\
\text { observed? }\end{array}$ & + & & & $\begin{array}{l}\text { The accounting policy establishes } \\
\text { the method of evaluation of } \\
\text { material resources at average } \\
\text { cost. The established method is } \\
\text { observed in the practical } \\
\text { activities of the economic } \\
\text { services. }\end{array}$ \\
\hline
\end{tabular}




\begin{tabular}{|l|l|l|l|}
\hline $\begin{array}{l}\text { 8. Is the method of accrual } \\
\text { of depreciation of fixed } \\
\text { assets established in the } \\
\text { accounting policy observed? }\end{array}$ & + & & $\begin{array}{l}\text { The linear method of depreciation } \\
\text { accrual is established in the } \\
\text { accounting policy. The } \\
\text { established method is observed in } \\
\text { the practical activities of the } \\
\text { economic services. }\end{array}$ \\
\hline $\begin{array}{l}\text { 9. Is there a reconciliation } \\
\text { of analytical accounting of } \\
\text { the costs of production? }\end{array}$ & + & & $\begin{array}{l}\text { Data of analytical accounting of } \\
\text { production costs are reconciled } \\
\text { once a month. }\end{array}$ \\
\hline $\begin{array}{l}10 \text { Does the accounting } \\
\text { policy establish a method } \\
\text { for allocating overhead } \\
\text { costs to calculation objects? }\end{array}$ & + & & $\begin{array}{l}\text { The accounting policy establishes } \\
\text { the method of overhead cost } \\
\text { allocation in proportion to direct } \\
\text { costs. }\end{array}$ \\
\hline $\begin{array}{l}11 . \text { Is the accounting of } \\
\text { costs that are included in the } \\
\text { cost of production correctly } \\
\text { organized? }\end{array}$ & + & $\begin{array}{l}\text { Accounting for costs that are } \\
\text { included in the cost of production } \\
\text { is organized in accordance with } \\
\text { the requirements of legislation. }\end{array}$ \\
\hline $\begin{array}{l}12 \text { Are direct costs } \\
\text { allocated correctly between } \\
\text { work in progress and } \\
\text { finished products? }\end{array}$ & + & $\begin{array}{l}\text { Direct costs are allocated in } \\
\text { proportion to the amount of raw } \\
\text { materials and supplies used. }\end{array}$ \\
\hline
\end{tabular}

Table 3. Internal Control Working Document (ICWD) «Test for assessing the system of internal control of production costs».

\begin{tabular}{|l|l|l|l|l|}
\hline & \multicolumn{2}{|c|}{ Answer Option } & \multicolumn{2}{|c|}{ Notes } \\
\cline { 2 - 3 } & Yes & No & Partially & \\
\hline $\begin{array}{l}\text { 1. Does the company have } \\
\text { established norms of } \\
\text { production costs? }\end{array}$ & + & & & $\begin{array}{l}\text { The enterprise has established } \\
\text { norms of production costs. }\end{array}$ \\
\hline $\begin{array}{l}\text { 2. Does the enterprise comply } \\
\text { with the established norms of } \\
\text { production costs? }\end{array}$ & + & & & $\begin{array}{l}\text { The standards of production } \\
\text { costs established at the } \\
\text { enterprise are observed in the } \\
\text { practical activities of the } \\
\text { economic services. }\end{array}$ \\
\hline $\begin{array}{l}\text { 3. Are the enterprise's set } \\
\text { standards of production costs } \\
\text { regularly reviewed? }\end{array}$ & + & & $\begin{array}{l}\text { The production cost standards } \\
\text { established at the enterprise are } \\
\text { regularly reviewed taking into } \\
\text { account the development of } \\
\text { equipment and technology. }\end{array}$ \\
\hline $\begin{array}{l}\text { 4. Does the enterprise develop a } \\
\text { document flow schedule for } \\
\text { accounting for production } \\
\text { costs? }\end{array}$ & + & $\begin{array}{l}\text { The company developed a } \\
\text { schedule of workflow in terms } \\
\text { of accounting for production } \\
\text { costs and calculating the cost of } \\
\text { production. }\end{array}$ \\
\hline $\begin{array}{l}\text { 5. Is the release of material } \\
\text { resources into production in } \\
\text { excess of the established limits } \\
\text { monitored? }\end{array}$ & + & & $\begin{array}{l}\text { There is constant and timely } \\
\text { control over the excessive } \\
\text { release of material assets into } \\
\text { production. }\end{array}$ \\
\hline $\begin{array}{l}\text { 6. Does the enterprise provide } \\
\text { for an inventory of work in } \\
\text { progress? }\end{array}$ & + & $\begin{array}{l}\text { Inventory of work in progress is } \\
\text { performed twice a year. This } \\
\text { fact is fixed in the accounting } \\
\text { policy, inventory schedule is } \\
\text { developed. }\end{array}$ \\
\hline $\begin{array}{l}\text { 7. Do the reports on the } \\
\text { movement of material assets } \\
\text { correspond to the data }\end{array}$ & + & $\begin{array}{l}\text { Data from reports on the } \\
\text { movement of material assets are } \\
\text { reconciled with the data of }\end{array}$ \\
\hline
\end{tabular}




\begin{tabular}{|l|l|l|l|}
\hline $\begin{array}{l}\text { contained in the primary } \\
\text { documents? }\end{array}$ & & $\begin{array}{l}\text { primary documents on a } \\
\text { monthly basis, }\end{array}$ \\
\hline $\begin{array}{l}\text { 8. Are the job descriptions of } \\
\text { employees } \\
\text { responsibilities for controlling } \\
\text { the operations of accounting for } \\
\text { production costs and costing of } \\
\text { products? }\end{array}$ & + & $\begin{array}{l}\text { Job descriptions of employees } \\
\text { define responsibilities for } \\
\text { controlling operations on } \\
\text { accounting for production costs } \\
\text { an calculating the cost of } \\
\text { production. }\end{array}$ \\
\hline $\begin{array}{l}\text { 9. Are expenses that are } \\
\text { rationed for taxation purposes } \\
\text { controlled? }\end{array}$ & + & $\begin{array}{l}\text { There is a current control of } \\
\text { costs, which are rationed for tax } \\
\text { purposes. }\end{array}$ \\
\hline $\begin{array}{l}\text { 10. Is the reasonableness of } \\
\text { overhead cost allocation by } \\
\text { calculation objects controlled? }\end{array}$ & + & $\begin{array}{l}\text { The current control over the } \\
\text { reasonableness of the } \\
\text { distribution of overhead costs by } \\
\text { objects of calculation is carried } \\
\text { out }\end{array}$ \\
\hline
\end{tabular}

Based on the internal control working papers presented in Tables 2 and 3, a conclusion can be made about the level of organization of accounting and internal control systems at the enterprise. Particular attention should be paid to questions that were answered negatively. Evaluating the system of accounting and internal control the controller receives the information about validity and reliability of accounting of production costs and calculation of the cost of production; about the control procedures used in the system of internal control of production costs and effectiveness of these procedures. Besides on the basis of test data the controller obtains information about general principles of organization of primary, synthetic and analytical manufacturing cost accounting, about rationing of material resources at an enterprise.

In the process of internal control of production costs it is necessary to check the accuracy of filling out primary documents, having previously become familiar with the rules of their registration in accordance with the regulations.

At this stage it is checked how the document flow at the enterprise is organized. In particular, the internal auditor determines the presence of an approved document flow schedule; establishes whether it corresponds to the actual document flow and the peculiarities of the activities of the economic entity. In addition, the forms of primary documents used for registration of business operations are established, as well as whether these forms are approved in the accounting policy or other local normative act of the enterprise.

Applying such method of control as a formal check, the controller checks the presence in the documents of all the requisites and signatures of persons who are responsible for their registration, establishes whether the documents have no unspecified corrections. Also, the data on operations on accounting for production costs, which are contained in the primary documents are compared with the circumstances confirming the possibility of these operations. Primary documents for which no violations are found are reflected in the working document as a common file, indicating their number, name and date of formation.

Documents that, in the controller's opinion, are questionable and contain errors should be reflected separately in the working document (Table 4). 
Table 4. Internal Control Working Document (ICWD) «Verification of Primary Production Cost Accounting».

\begin{tabular}{|c|c|c|c|c|c|c|}
\hline 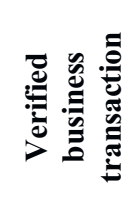 & 总 & 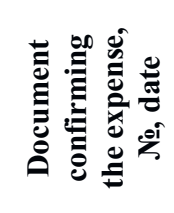 & 兽 & 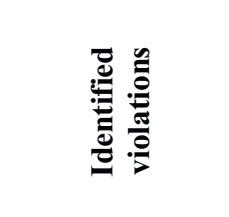 & 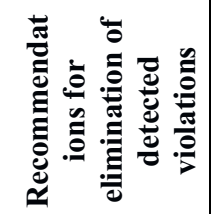 & 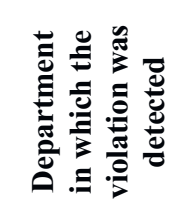 \\
\hline $\begin{array}{l}\text { 1. The } \\
\text { lathe } \\
\text { was } \\
\text { repaired }\end{array}$ & $\begin{array}{l}\text { Cylindrical } \\
\text { roller } \\
\text { bearing 2- } \\
3182116 \mathrm{~K}\end{array}$ & $\begin{array}{l}\text { Intra-farm } \\
\text { bill of } \\
\text { lading, } \\
16.09 .2020 \text {, } \\
\text { No. } 123\end{array}$ & 2930 & $\begin{array}{l}\text { 1. The recipient } \\
\text { structural unit is } \\
\text { not indicated. } \\
\text { 2. The number } \\
\text { of pleasant } \\
\text { material values } \\
\text { is not indicated. }\end{array}$ & $\begin{array}{l}\text { The recipient } \\
\text { structural unit } \\
\text { and the } \\
\text { number of } \\
\text { accepted } \\
\text { material } \\
\text { assets should } \\
\text { be indicated }\end{array}$ & $\begin{array}{l}\text { Spare parts } \\
\text { warehouse. } \\
\text { Repair shop }\end{array}$ \\
\hline
\end{tabular}

This document allows you to systematize the information obtained in the process of internal control of primary accounting. The peculiarity of this form is that it shows the division in which a violation is detected. Thus, the controller has an opportunity to determine the units in which the largest number of violations in the primary accounting is observed.

The next stage is to check how synthetic and analytical cost accounting is organized, whether it corresponds to the method of cost accounting and chart of accounts, which are set in the accounting policy of the enterprise. It is defined, what registers of synthetic and analytical cost accounting are used at the enterprise, these registers are compared with each other, for those accounts, which reflect business operations on accounting for production costs. Arithmetic check the totals in the registers of synthetic and analytical accounting. By tracing the reflection of the registers of synthetic and analytical accounting data contained in the primary documents is checked, the final correspondence of accounts is determined.

The next stage involves checking the accuracy of inclusion of costs in the cost of production, taking into account their classification by element of material costs, labor costs, deductions for social needs, depreciation of fixed assets and other costs.

When checking the accuracy of cost accounting it is assessed:

- compliance with the principle of constancy in cost accounting. According to this principle the company must always use in accounting practice the methods of cost accounting and costing, methods of distribution of overhead costs chosen at the beginning of the reporting period and approved in the accounting policy;

- compliance of the cost accounting method approved in the accounting policy with the peculiarities of the enterprise operation;

- correctness of differentiation of production costs by types of activity and by reporting periods;

- compliance with the chosen method of evaluation of inventories which are written off to production costs;

- accuracy of depreciation accrual for the objects of fixed assets;

- validity of general production and general business expenses and methods of their distribution on objects of accounting and calculation.

To establish the validity of material costs check documents that confirm the material costs of production, as well as consumption rates of material assets in kind. To summarize the results of checking the norms of consumption of inventories for production, we recommend using the following form of a working document (Table 5). 
Table 5. Internal Control Working Document (ICWD) «Verification of compliance with the norms of consumption of material inventories in production».

\begin{tabular}{|c|c|c|c|c|c|c|c|}
\hline \multirow{2}{*}{ 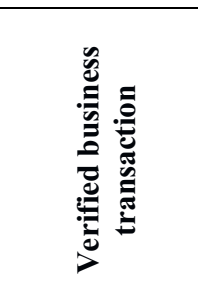 } & \multirow{2}{*}{ 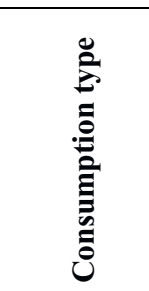 } & \multirow[b]{2}{*}{$\begin{array}{c}\text { Document } \\
\text { confirming } \\
\text { the } \\
\text { expense. } \\
\text { №. date }\end{array}$} & \multicolumn{3}{|c|}{$\begin{array}{c}\text { Expense amount. } \\
\text { rub. }\end{array}$} & \multirow[b]{2}{*}{ 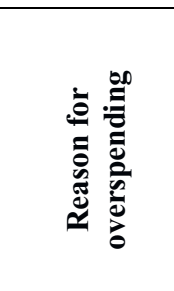 } & \multirow[b]{2}{*}{$\begin{array}{l}\text { Department } \\
\text { in which } \\
\text { overruns } \\
\text { are } \\
\text { detected }\end{array}$} \\
\hline & & & 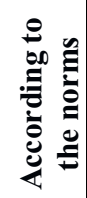 & 离 & 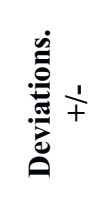 & & \\
\hline $\begin{array}{l}\text { Transportation } \\
\text { of organic } \\
\text { fertilizers with } \\
\text { simultaneous } \\
\text { spreading in } \\
\text { the field. } 6 \mathrm{~km}\end{array}$ & $\begin{array}{l}\text { Fuels and } \\
\text { lubricants }\end{array}$ & $\begin{array}{l}\text { Truck } \\
\text { waybill. } \\
\text { №. } 54 . \\
\text { September } \\
15.2020\end{array}$ & 4.41 & 4.52 & +1.11 & $\begin{array}{l}\text { Latent } \\
\text { technical } \\
\text { malfunction }\end{array}$ & $\begin{array}{l}\text { Machine } \\
\text { and tractor } \\
\text { park number } \\
1\end{array}$ \\
\hline
\end{tabular}

Checking the validity of labor costs it is necessary to compare the data of documents, which contain the calculation of payroll, with the data of documents, which present the results of personnel work.

Verification of validity of cost accounting and costing methods used at the enterprise is carried out on the basis of studying provisions of accounting policy and specifics of production activity. It should be taken into account that enterprises can use normative and non-normative methods of accounting for costs and calculating the cost of production. Nonnormative methods are subdivided into piece-by-piece, item-by-item, piece-by-process methods.

The piece-by-piece method is used in those productions, where raw materials are consistently processed in separate independent process stages. As a result of processing raw materials in each stage, a semi-finished product is obtained. Finished products are obtained in the last stage.

Verification by the piece-by-piece method of cost accounting and costing includes the following steps:

- verification of documentation and accounting of direct and indirect costs;

- verification of grouping of direct costs by redistribution;

- verification of indirect costs allocation to the processing lines;

- verification of correctness of determination of costs for the month for the i-th partition;

- verification of correctness of determination of unit cost of a semi-finished product;

- verification of correct determination of the cost of semi-finished products, which are transferred to $\mathrm{i}+1$ process stage;

- checking the correctness of determining the cost of production of finished products;

- checking the correctness of determining the unit cost of finished products.

Under the order-based method, production costs are summarized by individual orders. In this case, the object of cost accounting and calculation is a production order, the basis for opening which is a contract with the customer.

When verifying the correctness of accounting operations under the order-based method, control measures are performed on the following stages:

- checking the correctness of documenting and accounting of direct and indirect costs;

- verification of correctness of direct costs in the cost price of the order;

- verification of correct distribution of indirect costs by orders;

- verification of total costs for each order executed;

- verification of correctness of determination of actual cost value of each order.

When checking the accuracy of accounting operations for the process method should be 
considered that the accounting of direct and indirect costs is conducted for the entire volume of products manufactured by costing items. To determine the average unit cost of production, the total amount of costs divided by the number of products manufactured during the reporting period. It is possible to allocate the following basic stages of checking the correctness of accounting at the process method of accounting:

- checking the correctness of documenting and accounting of costs by items and elements;

- checking of correct distribution of costs by processes;

- to check that the total costs for the month are being determined correctly;

- verification of correct distribution of costs between the output of finished products and work in progress; between several types of products;

- verification of the correctness of determining the cost of goods manufactured.

In the process of internal control, it is established whether the method of cost accounting and calculation of the cost, which is actually used in the production activities, corresponds to the method of accounting, justified in the accounting policy. In this case, the accounting method, fixed in the accounting policy, must meet the peculiarities of the technological process.

Verification of itemized cost accounting implies the following control measures:

1) Checking the correctness of the distribution of basic costs on the objects of calculation. To do this it is necessary to establish how costs are included in the cost of this or that type of product: direct or indirect method. In the direct method on the basis of primary documents can be established, to which type of product costs relate. If it is impossible to determine from the documents what type of products costs relate to, they are allocated by the indirect method. In this regard, the controller needs to: determine which indirect method of distribution is established in the accounting policy and its compliance with technological features; check whether the basis for allocation is correctly applied; check the correctness of the distribution of costs.

Also, when controlling material costs determine:

- whether the established norms of material resources supply in production by the enterprise's subdivisions are complied with;

- whether there is control over deviations from the norms;

- whether the causes of deviations are analyzed.

2) Checks the accuracy of accounting and distribution of overhead costs on the objects of calculation.

When checking the correctness of accounting overhead evaluates their distribution by product. To do this it is established, whether the method of allocation of overhead costs selected in the accounting policies of the conditions of functioning of the enterprise and whether the selected method in the practical activities of the economic services. Depending on the organization of production overhead costs may be distributed in proportion to the following basis: the basic salary of production workers, production volume, direct costs for certain types of products

By means of mutual verification of accounting registers and arithmetic control is performed to check the completeness of the reflection of costs for each item.

3) The correctness of accounting and distribution of costs of auxiliary industries is checked.In the course of inspection the composition of costs is established and their grouping and distribution by types of products manufactured is assessed. To do this, the controller, applying arithmetic control, checks entries in accounting registers. Operations on calculation of actual cost of products, works and services of auxiliary productions, which depend on auxiliary productions type: simple or complex, are subject to separate control.

Verification of simple auxiliary productions characterized by a single-period technological cycle and engaged in the production of homogeneous products consists in 
arithmetic calculations of the unit cost of production by simply dividing all costs by the volume of goods produced, work performed and services rendered.

Verification of complex auxiliary production facilities, performing several types of work and services is the arithmetic control of the calculation of the actual cost of each type of products, works and services for individual items of calculation and orders.

Reconciliation of auxiliary production accounting registers confirms whether entries on the formation and distribution of costs are recorded correctly.

During internal control of production accounting organization of work in progress accounting is subject to separate verification. In particular, it is assessed how timely and correctly inventory was taken, how results of inventory are reflected in the accounting. To develop the internal control of work in progress we suggest to use the working document of internal control «Questionnaire of assessment of the organization and accounting of work in progress inventory» (table 6).

Table 6. Internal Control Working Document (ICWD) «Questionnaire for assessment of organization and accounting of work in progress inventory».

\begin{tabular}{|l|l|}
\hline \multicolumn{1}{|c|}{ Questions } & \multicolumn{1}{|c|}{ Answer } \\
\hline $\begin{array}{l}\text { 1. Does the enterprise carry out an } \\
\text { inventory of work in progress? }\end{array}$ & Inventory is carried out 12 times a year \\
\hline $\begin{array}{l}\text { 2. Is there an order to conduct an } \\
\text { inventory }\end{array}$ & $\begin{array}{l}\text { The company has an order to conduct an } \\
\text { inventory }\end{array}$ \\
\hline $\begin{array}{l}\text { 3. Are inventory and collation sheets } \\
\text { completed? }\end{array}$ & $\begin{array}{l}\text { Based on the results of the inventory, inventory } \\
\text { and collation statements are filled out }\end{array}$ \\
\hline $\begin{array}{l}\text { 4. Are there any deviations in the } \\
\text { inventory and collation statements? }\end{array}$ & $\begin{array}{l}\text { No deviations were found in the inventory and } \\
\text { collation statements. }\end{array}$ \\
\hline $\begin{array}{l}\text { 5. What types of assets are part of work in } \\
\text { progress? }\end{array}$ & $\begin{array}{l}\text { Work in progress includes products that have not } \\
\text { passed all stages of processing and products that } \\
\text { have not passed technical acceptance. }\end{array}$ \\
\hline $\begin{array}{l}\text { 6. Does the composition of work in } \\
\text { progress comply with the requirements of } \\
\text { regulatory enactments? }\end{array}$ & $\begin{array}{l}\text { The composition of the work in progress } \\
\text { complies with the requirements of regulatory } \\
\text { enactments. }\end{array}$ \\
\hline 7. Is there a need for a sample inventor & There is no need to conduct a sample inventory. \\
\hline
\end{tabular}

The control procedures are carried out in the following sequence:

- compliance with the timing and procedure for taking inventory and their compliance with the requirements of regulatory acts is assessed;

- an arithmetic check of the inventory and reconciliation sheets is performed. If there are no deviations revealed in these documents, the inspector draws conclusions about the formal approach to conducting an inventory, or about well-organized accounting;

- in enterprises using the semi-finished method of cost accounting, an internal controller may apply such method of control as random inventory of work in progress. The purpose of such inspection is to confirm the volumes of work in progress specified in analytical or operational accounting;

- the correctness of assessment of unfinished production and application of established norms and standards at the enterprise is confirmed. For this purpose arithmetical control of calculated indices is used.

Since in modern conditions the problems connected with reduction of costs of production become especially urgent, there is a necessity of analysis of costs of production and cost of production in the process of internal control.

In the process of analysis the following tasks are solved:

- systematic control over the planned reduction of production costs;

- the fulfillment of the plan in the context of elements and cost items is evaluated:

- the influence of factors on the cost of production is assessed; 
- reserves for reducing the cost of production are identified:

- evaluated measures that are implemented by the enterprise to reduce the cost of production;

- the measures are developed, which are directed to the development of the identified reserves.

The main principles of the analysis of production costs are:

- rationality - implies the definition of such a set of indicators that do not duplicate each other and allow a comprehensive assessment of the activities of the enterprise;

- sufficiency - information received in the course of the analysis of production costs, should be sufficient for making effective managerial decisions;

- timeliness - the results of the analysis shall be timely provided to the management of the enterprise in order to make effective management decisions;

- practicality - the indicators received in the course of the analysis, should be applied and serve as a basis for an estimation of industrial and financial activity

- completeness-the analyzed indicators should characterize the impact of internal and external environment factors that affect the functioning of the enterprise in full.

In the economic literature it is accepted to allocate the following stages of the analysis:

1) The composition, structure and dynamics of costs by elements is analyzed, namely: the specific weight of the economic element in total production costs is determined (Table 7).

Table 7. Cost analysis by economic elements.

\begin{tabular}{|l|c|c|c|c|c|c|}
\hline \multirow{2}{*}{$\begin{array}{c}\text { Cost } \\
\text { elements }\end{array}$} & \multirow{2}{*}{$\begin{array}{c}\text { Plan. } \\
\text { thousan } \\
\text { d rubles. }\end{array}$} & \multirow{2}{*}{$\begin{array}{c}\text { Actual. } \\
\text { thousand } \\
\text { rubles. }\end{array}$} & \multicolumn{2}{|c|}{ Cost structure. \% } & \multicolumn{2}{c|}{ Deviations } \\
\cline { 5 - 7 } & 23634 & 24019 & 52.8 & 52.9 & +385 & +0.1 \\
\hline Material costs & 23453 & 9507 & 21.1 & 21.0 & +54 & -0.1 \\
\hline Labor costs & 2836 & 2852 & 6.3 & 6.3 & +16 & - \\
\hline $\begin{array}{l}\text { Social } \\
\text { Security } \\
\text { contributions }\end{array}$ & 276 & & & & abs.. thous. \\
rub. & $\begin{array}{c}\text { by } \\
\text { structure. } \\
\%\end{array}$ \\
\hline Depreciation & 2716 & 2760 & 6.1 & 6.1 & +44 & - \\
\hline Other costs & 6144 & 6209 & 13.7 & 13.7 & +65 & - \\
\hline TOTAL & 44783 & 45347 & 100 & 100 & +564 & - \\
\hline
\end{tabular}

As it can be seen from Table 7, material costs $52,9 \%$ and labor costs $21 \%$ occupy the greatest specific weight in the cost structure in the reporting period. In absolute terms the deviation of actual costs from planned ones is 564 thousand rubles. And the deviations are observed for all cost elements. At the same time in the structure of costs the deviation of actual indicators from planned ones is observed only in material costs and labor costs.

Thus, in the process of analysis of costs by elements the dynamics of changes in the cost structure in the reporting period compared to the plan is determined, the reasons for changes are determined. The results of the analysis are interpreted taking into account specifics of functioning of the enterprise and strategic goals of its development.

The amount of material costs may change as a result of changes in prices for material resources used in production, and changes in production volumes.

The amount of labor costs and social contributions may change depending on changes in the value of wages or changes in the number of employees of the enterprise. The amount of deductions for social needs is also affected by changes in legislation related to changes in insurance premium rates.

In addition, an increase in the share of material costs and a decrease in the share of labor costs may indicate an increase in social productivity.

An increase or decrease in the share of depreciation is connected with changes in the 
technical level of production. Fluctuations in the share of other costs may be associated with a reduction or increase in general production and general business expenses.

2) Analysis of production costs by costing items allows for detailed analytical studies to determine the functional role of costs in the production process and study the dynamics of costs to further identify the reserves to reduce costs and improve the efficiency of business processes.

The analysis of production costs by costing items involves:

- determination of deviations in absolute and relative terms of the actual cost of production from the planned one;

- determination of deviations by individual calculation items:

- establishing the general reasons that caused deviations in the context of each cost item;

- development of recommendations aimed at reducing costs in those items for which cost overruns are identified.

The reasons for the increase in costs for a single article may be associated with measures aimed at an overall reduction in the cost of production and improvement of the efficiency of the enterprise. For example, the increase in the amount of depreciation and maintenance costs of fixed assets can be associated with the implementation of innovative technologies. At the same time, the introduction of innovative technologies makes it possible to increase labor productivity and, consequently, reduce labor costs.

Let's analyze the costs according to the calculation items (table 8).

Table 8. Cost analysis by calculation items.

\begin{tabular}{|c|c|c|c|c|c|c|}
\hline \multirow[b]{2}{*}{ Expenditures } & \multirow{2}{*}{$\begin{array}{l}\text { Plan. } \\
\text { thousand } \\
\text { rubles }\end{array}$} & \multirow{2}{*}{$\begin{array}{l}\text { Fact. } \\
\text { thousand } \\
\text { rubles }\end{array}$} & \multicolumn{2}{|c|}{$\begin{array}{c}\text { Cost structure. } \\
\%\end{array}$} & \multicolumn{2}{|c|}{ Deviations } \\
\hline & & & plan & actual & $\begin{array}{l}\text { abs.. } \\
\text { thous. } \\
\text { rub. }\end{array}$ & $\begin{array}{c}\text { by } \\
\text { structure. } \\
\%\end{array}$ \\
\hline $\begin{array}{l}\text { Raw material and } \\
\text { Supplies }\end{array}$ & 39110 & 34078 & 25.6 & 24.3 & -5032 & -1.3 \\
\hline $\begin{array}{l}\text { Purchased products } \\
\text { and semi-finished } \\
\text { products }\end{array}$ & 17409 & 15420 & 11.4 & 11.0 & -1989 & -0.4 \\
\hline $\begin{array}{l}\text { Fuel and energy for } \\
\text { technological } \\
\text { purposes }\end{array}$ & 905 & 921 & 0.6 & 0.7 & +16 & +0.1 \\
\hline Salary & 42086 & 38181 & 27.6 & 27.3 & -3905 & -0.4 \\
\hline Social Contribution & 12626 & 11454 & 8.3 & 8.2 & -1081 & $\begin{array}{l}-0.1 \\
\end{array}$ \\
\hline $\begin{array}{l}\text { Preparation and } \\
\text { development costs }\end{array}$ & 2310 & 2294 & 1.5 & 1.6 & -16 & +0.1 \\
\hline $\begin{array}{l}\text { Equipment } \\
\text { maintenance and } \\
\text { operating costs }\end{array}$ & 9644 & 9296 & 6.3 & 6.6 & -348 & $=0.3$ \\
\hline $\begin{array}{l}\text { General production } \\
\text { costs }\end{array}$ & 11853 & 11586 & 7.8 & 8.3 & -267 & +0.5 \\
\hline $\begin{array}{l}\text { General running } \\
\text { costs }\end{array}$ & 16578 & 16663 & 10.9 & 11.9 & +85 & $=1.0$ \\
\hline $\begin{array}{ll}\text { Losses } & \text { from } \\
\text { marriage } & \\
\end{array}$ & - & 61 & - & 0.1 & +61 & +0.1 \\
\hline $\begin{array}{l}\text { Other production } \\
\text { costs }\end{array}$ & - & - & - & - & & -- \\
\hline TOTAL & 152521 & 139954 & 100 & 100 & -12476 & - \\
\hline
\end{tabular}

As it is seen from table 8 the actual cost of production is lower than the planned one by 12476 thousand rubles. The largest savings are observed in the articles «Raw materials and 
supplies» and «Labor costs» by 5032 thousand rubles and 3905 thousand rubles, respectively. In such items as «Fuel and energy for technological purposes», «General business expenses» and «Losses from defective work» there is an overspending of 162 thousand rubles. Consequently, special attention should be paid to these items during internal control.

However, it is necessary to carry out a detailed analysis of other items, which can reveal reserves to reduce costs and increase the efficiency of production activities.

At the analysis of the cost of production the report calculations by separate kinds of production are analyzed, the actual expenses are compared with planned and with indicators of the previous reporting periods.

A number of factors influence the change in the unit cost of production. To study the influence of these factors, a factor model is used (Table 9):

$$
C i=\frac{\mathrm{FiCi}}{\mathrm{V} i}+\mathrm{VCi}
$$

where, $\mathrm{C} i$ - Unit cost, rub,

$\mathrm{FiCi}$ - fixed costs, thousand rubles,

$\mathrm{Vi}$ - production volume, pcs;

VCi- variable costs, thousand rubles.

Table 9. Data for factor analysis of production costs.

\begin{tabular}{|l|c|c|c|}
\hline \multicolumn{1}{|c|}{ Indicator } & Plan & Actual & $\begin{array}{c}\text { Deviation from the } \\
\text { plan }\end{array}$ \\
\hline Volume of production, pcs. & 6336 & 5544 & -792 \\
\hline Fixed costs, thous. rubles & 7603 & 7761 & +158 \\
\hline Variable costs, thous. rubles & 3080 & 3410 & +330 \\
\hline The cost of 1 pc. & 4280 & 4810 & +530 \\
\hline
\end{tabular}

Using the method of chain substitutions, we will calculate the influence of factors on the change in the cost of production

$$
\begin{gathered}
\mathrm{Cpl}=\frac{\mathrm{FiCpl}}{\mathrm{Vpl}}+V C p l=\frac{7603000}{6336}+3080=4280 \mathrm{rub} . \\
\text { Cterm } 1=\frac{F i C p l}{\mathrm{Va}}+V C p l=\frac{7603000}{5544}+3080=4451 \mathrm{rub} . \\
\text { Cterm2 }=\frac{A c C f}{\mathrm{Va}}+V C p l=\frac{7761000}{5544}+3080=4480 \mathrm{rub} . \\
C a=\frac{A c C f}{\mathrm{Va}}+\mathrm{VCa}=\frac{7761000}{5544}+3410=4810 \mathrm{rub} .
\end{gathered}
$$

where $\mathrm{Cpl}$ - unit production cost of the planned, rubles;

FiCpl - fixed planned cost, thousand rubles;

$\mathrm{Vpl}$ - volume of production planned, pcs;

VCpl - variable cost planned, thousand rubles;

Cterm1 - unit cost of production when changing the first condition - changes in production volume, rubles;

$\mathrm{Va}$ - volume of actual production, pcs;

Cterm2 - unit cost of production when changing the second condition - changes in fixed costs, rubles;

AcCf -actual cost fixed, thousand rubles;

$\mathrm{Ca}$ - the unit cost of production actual, rubles;

$\mathrm{VCa}$ - variable actual cost, thousand rubles.

The total change in the unit cost is: 


$$
\Delta \mathrm{Cot}=\mathrm{Ca}-\mathrm{Cpl}=4810-4280=+530 \text { rubles, }
$$

where $\Delta$ Cot is the total change in the cost of a unit of production, rubles.

Including due to changes:

a) the volume of production:

$$
\Delta \mathrm{Cvp}=\mathrm{Cterm} 1-\mathrm{Cpl}=4451-4280=+171 \text { rubles, }
$$

where, $\Delta \mathrm{Cvp}$ is the change in the cost of production due to changes in the volume of production, rubles;

b) the amount of fixed costs:

$$
\Delta \mathrm{Ca}=\text { Cterm2- } \text { Cterm } 1=4480-4451=+29 \text { rubles, }
$$

where, $\Delta \mathrm{Ca}$ - change in the cost of production due to changes in the amount of fixed costs, rubles;

c) the amount of unit variable costs:

$$
\Delta \mathrm{Cb}=\mathrm{Ca}-\mathrm{Cterm} 2=4810-4480=+330 \text { rubles. }
$$

where, $\Delta \mathrm{Cb}$ is a change in the cost of production due to a change in the amount of unit variable costs, rubles.

Having carried out the analysis of the unit cost of production, it is possible to draw a conclusion that the change in the unit cost of production was influenced by the volume of production by 171 rubles, the sum of fixed costs by 29 rubles and the sum of specific variable costs by 330 rubles.

Thus, the results of the analysis of production costs and costing allow:

- objectively assess the implementation of planned indicators on the cost of production, its dynamics in comparison with previous reporting periods;

- investigate the reasons that influenced the deviation of actual indicators from the planned ones;

- contribute to the development of proposals for determining the optimal planned values of costs and planned calculations of certain types of products;

- identify the reserves for reducing the cost of production.

To summarize the results of the audit and the reflection of violations and errors detected during the internal control we recommend to use the working document of internal control (Table 10). This document contains a list of violations, systematized by areas of inspection

\begin{tabular}{|c|c|c|c|c|c|c|}
\hline ש气 & 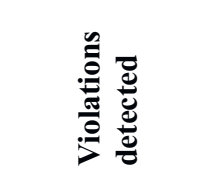 & 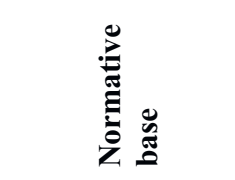 & 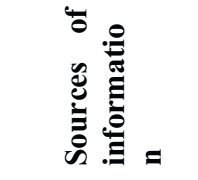 & 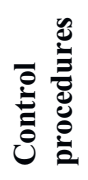 & 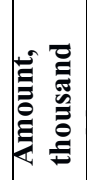 & 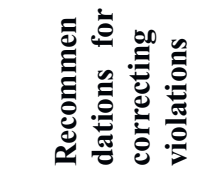 \\
\hline $\begin{array}{l}\text { 1. } \\
\text { Checkin } \\
\mathrm{g} \text { the } \\
\text { primary } \\
\text { accounti } \\
\text { ng of } \\
\text { producti } \\
\text { on costs }\end{array}$ & $\begin{array}{l}1 . \quad \text { In the } \\
\text { primary } \\
\text { documents } \\
\text { that take into } \\
\text { account } \\
\text { production } \\
\text { costs, there } \\
\text { are no } \\
\text { separate } \\
\text { details }\end{array}$ & $\begin{array}{l}\text { Federal Law «On } \\
\text { Accounting» }\end{array}$ & $\begin{array}{l}\text { Primary } \\
\text { documents for } \\
\text { accounting for } \\
\text { production } \\
\text { costs }\end{array}$ & 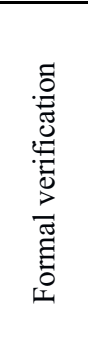 & & $\begin{array}{l}\text { Recommendati } \\
\text { ons for filling } \\
\text { in all details }\end{array}$ \\
\hline
\end{tabular}
and recommendations for their elimination.

Table 10. Internal Control Working Document (ICWD) «Identified violations in the accounting of production costs and costing of products». 


\begin{tabular}{|c|c|c|c|c|c|c|}
\hline & $\begin{array}{l}2 . \quad \text { The } \\
\text { workflow } \\
\text { schedule for } \\
\text { the operations } \\
\text { of writing off } \\
\text { material } \\
\text { assets into } \\
\text { production is } \\
\text { not drawn up } \\
\text { for all } \\
\text { primary } \\
\text { documents }\end{array}$ & $\begin{array}{l}\text { Federal Law «On } \\
\text { Accounting» }\end{array}$ & $\begin{array}{l}\text { Primary } \\
\text { documents for } \\
\text { accounting for } \\
\text { production } \\
\text { costs, } \\
\text { workflow } \\
\text { schedule }\end{array}$ & 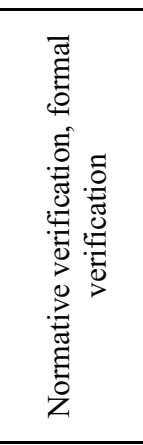 & & $\begin{array}{l}\text { Recommendati } \\
\text { ons for the } \\
\text { inclusion in the } \\
\text { workflow } \\
\text { schedule of all } \\
\text { primary } \\
\text { documents for } \\
\text { accounting for } \\
\text { production } \\
\text { costs. }\end{array}$ \\
\hline $\begin{array}{l}2 . \\
\text { Verificat } \\
\text { ion of } \\
\text { synthetic } \\
\text { and } \\
\text { analytica } \\
1 \\
\text { accounti } \\
\text { ng of } \\
\text { producti } \\
\text { on costs }\end{array}$ & $\begin{array}{l}\text { 1. Data of } \\
\text { analytical } \\
\text { accounting of } \\
\text { costs does not } \\
\text { correspond to } \\
\text { turnovers and } \\
\text { balances on } \\
\text { accounts of } \\
\text { synthetic } \\
\text { accounting of } \\
\text { production } \\
\text { costs }\end{array}$ & $\begin{array}{l}\text { Accounting } \\
\text { Regulation 10/99 } \\
\text { «Expenses of the } \\
\text { organization»; } \\
\text { Plan of accounts } \\
\text { for financial and } \\
\text { economic } \\
\text { activities of } \\
\text { organizations } \\
\text { and instructions } \\
\text { for its } \\
\text { application }\end{array}$ & $\begin{array}{l}\text { Synthetic and } \\
\text { analytical } \\
\text { accounting } \\
\text { registers }\end{array}$ & 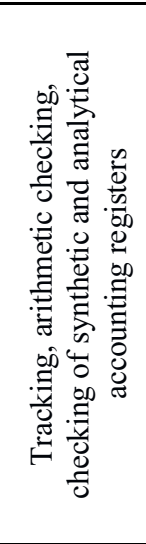 & $\begin{array}{l}\infty \\
\stackrel{n}{n} \\
\cong \\
\end{array}$ & $\begin{array}{l}\text { Recommendati } \\
\text { ons on the } \\
\text { observance of } \\
\text { the identity of } \\
\text { the data of } \\
\text { analytical } \\
\text { accounting of } \\
\text { costs with } \\
\text { turnovers and } \\
\text { balances on } \\
\text { accounts of } \\
\text { synthetic } \\
\text { accounting of } \\
\text { production } \\
\text { costs. }\end{array}$ \\
\hline \multirow{2}{*}{$\begin{array}{l}3 . \\
\text { Checkin } \\
\mathrm{g} \text { the } \\
\text { feasibilit } \\
\mathrm{y} \text { of } \\
\text { producti } \\
\text { on costs }\end{array}$} & $\begin{array}{l}\text { 1. Failure to } \\
\text { comply with } \\
\text { the } \\
\text { consumption } \\
\text { of material } \\
\text { assets in the } \\
\text { production of } \\
\text { products }\end{array}$ & $\begin{array}{l}\text { Accounting } \\
\text { Regulation 10/99 } \\
\text { «Expenses of the } \\
\text { organization»; } \\
\text { Industry } \\
\text { guidelines for } \\
\text { cost accounting } \\
\text { and product } \\
\text { costing }\end{array}$ & $\begin{array}{l}\text { Primary } \\
\text { documents for } \\
\text { accounting for } \\
\text { production } \\
\text { costs, } \\
\text { accounting } \\
\text { registers, } \\
\text { business plan, } \\
\text { estimates }\end{array}$ & 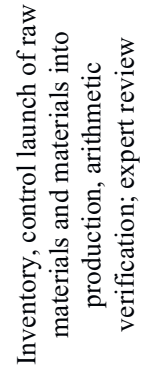 & 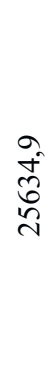 & $\begin{array}{l}\text { Recommendati } \\
\text { ons for } \\
\text { compliance } \\
\text { with the } \\
\text { consumption of } \\
\text { material assets } \\
\text { in the } \\
\text { production of } \\
\text { products. }\end{array}$ \\
\hline & $\begin{array}{l}2 . \quad \text { The } \\
\text { company } \\
\text { does not have } \\
\text { estimates of } \\
\text { entertainment } \\
\text { expenses for } \\
\text { the reporting } \\
\text { period }\end{array}$ & $\begin{array}{l}\text { Accounting } \\
\text { Regulation 10/99 } \\
\text { «Expenses of the } \\
\text { organization»; } \\
\text { Industry } \\
\text { guidelines for } \\
\text { cost accounting } \\
\text { and product } \\
\text { costing }\end{array}$ & $\begin{array}{l}\text { Business plan, } \\
\text { estimates }\end{array}$ & 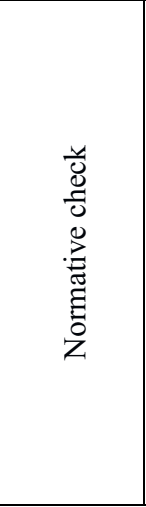 & & $\begin{array}{l}\text { Recommendati } \\
\text { ons for the } \\
\text { development of } \\
\text { estimates in } \\
\text { order to } \\
\text { document the } \\
\text { legitimacy of } \\
\text { entertainment } \\
\text { expenses and } \\
\text { prevent } \\
\text { unjustified } \\
\text { overstatement } \\
\text { of the cost of } \\
\text { production. }\end{array}$ \\
\hline
\end{tabular}




\begin{tabular}{|c|c|c|c|c|c|c|}
\hline $\begin{array}{l}4 . \\
\text { Checkin } \\
\text { g line- } \\
\text { by-line } \\
\text { cost } \\
\text { accounti } \\
\text { ng }\end{array}$ & $\begin{array}{l}1 . \\
\text { procedure for } \\
\text { the } \\
\text { distribution of } \\
\text { overhead } \\
\text { costs } \\
\text { determined in } \\
\text { the } \\
\text { accounting } \\
\text { policy of the } \\
\text { enterprise is } \\
\text { not respected }\end{array}$ & $\begin{array}{l}\text { Industry } \\
\text { guidelines for } \\
\text { cost accounting } \\
\text { and product } \\
\text { costing }\end{array}$ & $\begin{array}{l}\text { Accounting } \\
\text { policy of the } \\
\text { enterprise, } \\
\text { primary } \\
\text { documents for } \\
\text { accounting for } \\
\text { production } \\
\text { costs, } \\
\text { accounting } \\
\text { registers }\end{array}$ & 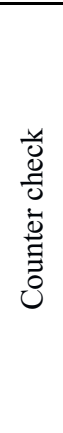 & 1 & $\begin{array}{l}\text { Recommendati } \\
\text { ons on the } \\
\text { observance of } \\
\text { the procedure } \\
\text { for the } \\
\text { distribution of } \\
\text { overhead costs } \\
\text { determined in } \\
\text { the accounting } \\
\text { policy }\end{array}$ \\
\hline \multirow{2}{*}{$\begin{array}{l}6 . \\
\text { Evaluati } \\
\text { on of the } \\
\text { results of } \\
\text { the } \\
\text { inventor } \\
y \text { of } \\
\text { work in } \\
\text { progress }\end{array}$} & $\begin{array}{l}\text { 1. Revealed } \\
\text { deviations in } \\
\text { the inventory } \\
\text { and collation } \\
\text { statements } \\
\text { based on the } \\
\text { results of the } \\
\text { inventory of } \\
\text { work in } \\
\text { progress }\end{array}$ & $\begin{array}{l}\text { Methodical } \\
\text { instructions on } \\
\text { the inventory of } \\
\text { property and } \\
\text { financial } \\
\text { liabilities. Order } \\
\text { of the Ministry } \\
\text { of Finance of the } \\
\text { Russian } \\
\text { Federation of } \\
13.06 .1995 \text { г. № } \\
49\end{array}$ & $\begin{array}{l}\text { Inventory } \\
\text { lists, collation } \\
\text { statements, } \\
\text { Inventory plan } \\
\text { of property } \\
\text { and liabilities }\end{array}$ & 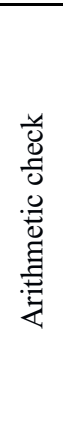 & $\begin{array}{l}\overrightarrow{8} \\
0 \\
=\end{array}$ & $\begin{array}{l}\text { Recommendati } \\
\text { ons for } \\
\text { correcting } \\
\text { inventories and } \\
\text { collation } \\
\text { statements }\end{array}$ \\
\hline & $\begin{array}{l}\text { 2. Incorrect } \\
\text { corresponden } \\
\text { ce of } \\
\text { accounts to } \\
\text { reflect the } \\
\text { results of } \\
\text { inventory }\end{array}$ & $\begin{array}{l}\text { Methodical } \\
\text { instructions on } \\
\text { the inventory of } \\
\text { property and } \\
\text { financial } \\
\text { liabilities. Order } \\
\text { of the Ministry } \\
\text { of Finance of the } \\
\text { Russian } \\
\text { Federation of } \\
13.06 .1995 \text { г. № } \\
49\end{array}$ & $\begin{array}{l}\text { Inventory } \\
\text { lists, collation } \\
\text { statements, } \\
\text { Inventory plan } \\
\text { of property } \\
\text { and liabilities }\end{array}$ & 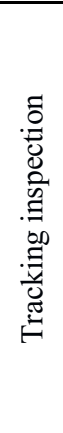 & 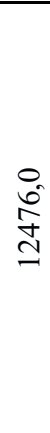 & $\begin{array}{l}\text { Recommendati } \\
\text { ons for } \\
\text { correcting the } \\
\text { correspondence } \\
\text { of invoices }\end{array}$ \\
\hline
\end{tabular}

\section{Discussion}

As is known, management of the organization is impossible without the availability of accurate and timely information about its state, which, in turn, is the basis for effective managerial and financial decisions. It is possible to agree with opinion of some authors that in the domestic enterprises one of the main sources of management information is accounting, historically bearing management load. Thus, accounting registers annually gather information about costs by elements, items, places of origin, formation of production costs by calculation groups, etc., which allows to maintain the managerial orientation of accounting $[27,28]$.

At the same time it would not be quite appropriate to use accounting as the main source of information for managers, since certain specifics on the order of reflection of business operations impose fiscal purposes, which, in particular, involve the formation of complex contractual schemes that minimize taxation within the limits established by law. Also an important role is played in practice by the principles of prudence and requirements to document business operations. This in practice leads to the fact that accounting entries appear in a few weeks or even months after the reporting period. In this connection in the 
subdivisions of organizations operational accounting of contracts and relations with counterparties, movement of material assets, receipts and payments is formed, the feature of which is the exclusive focus on management purposes, as well as the use of undocumented sources of information, forecast estimates, etc. This fact, in turn, affects the organization of internal control at the enterprise.

In this regard, we consider it necessary to improve the enterprise management system, including the development of internal control, to use internal reporting data in organizations within a single information space of accounting information based on ERP-system [29, 30]. All actual data are entered into this system once, and then are reflected either only in accounting or only in operational accounting, or simultaneously in these two types of accounting. Comparison of data from sales, supply, financial department and other departments with accounting data becomes an elementary automated procedure, performed at any frequency at the request of the user.

Issues of implementation of ERP-system acquire special relevance in those organizations that have many geographically remote units, using different methods of accounting, different computer systems that do not allow to integrate different indicators necessary for management. For modern effective management of a large enterprise it is necessary to implement advanced information technologies that allow: to provide information interaction of all participants of business processes, to promptly process primary documents and receive arbitrary reporting forms for managers of different management levels; to analyze the information obtained and make effective management decisions [31, 32].

ERP system (Enterprise Resource Planning System) is a corporate information system (CIS) designed to automate accounting and management. The concept of ERP was proposed by the analyst firm GartnerGroup in the early 1990s [Keller 96] and has already confirmed its viability. But also ERP is not the last word in enterprise management concepts. In addition, along with ERP in publications you can find many foreign-language names and acronyms, such as MRP and MRP II, CAD/CAM/CAE, PDM, MES, OPT, CIM, SCM, CRM, CALS, COMMS, etc.

A fairly widespread use in the manufacturing sector of the concept of ERP is explained by the effectiveness of resource planning for virtually all commercial activities of the organization, which can reduce the time of production, reduce inventory levels, reduce errors in production and financial and economic calculations, improve the quality of forecasting and planning, improve feedback to the customer while reducing the number of administrative staff. In addition, the need to use ERP-systems in Russian practice is explained by the need to manage the production and financial activities under conditions of inflation, supplier instability and other factors that have a significant impact on the processes taking place in the organization. Planning with the use of ERP-system is realized in a single information space, in which the formation of interconnected data collected by organizations in the process of financial and economic activities takes place. In this case, there is no need to transfer data from one management subsystem to another. Moreover, access is provided for all employees with appropriate authority, to any part of the information that the companies have, which becomes simultaneously available within the unified system of access distribution.

At the same time, some authors note certain shortcomings in the functioning of the MRP II / ERP system (Table 11) [33].

Table 11. Disadvantages and advantages of the ERP system.

\begin{tabular}{|c|c|}
\hline Disadvantages of ERP & ERP advantages \\
\hline Inner focus & Lower cost through efficient operations \\
\hline $\begin{array}{c}\text { Functions limited to production and } \\
\text { administration }\end{array}$ & Reduced time to market \\
\hline
\end{tabular}




\begin{tabular}{|c|c|}
\hline Delayed reaction to market changes & Reduced costs and rejects \\
\hline $\begin{array}{c}\text { Operational efficiency can be copied and } \\
\text { improved by a competitor }\end{array}$ & Improving product quality \\
\hline & Closed loop order processing \\
\hline
\end{tabular}

These shortcomings have led to the emergence of the next level of management standards - the concept of ERP II (enterprise resource and relationship planning), or resource and external relationship planning of the organization. This concept appeared as a result of integration of methodology ERP with methodologies of relations with customers and suppliers, development of Internet technologies, and also introduction of complex data storages. The concept includes a block in the information system of the organization, interacting with the outside world. ERP II is a business and application building strategy that builds on, transforms ERP systems, turning the information circulating in the organization into a tool for building cooperation outside the organization on the interests.

Typified ERP systems implement the following major functional blocks: sales and production planning, demand management, aggregate capacity planning, master production plan (production schedule), material requirements planning, product specification, capacity requirements planning, routing/work centers, checking and adjusting shop floor capacity plans, purchasing, inventory, sales, financial management, cost management, project/program management, project/program management, management 3).

In the article we propose the structure of ERP-system for commercial organization (Fig.

In the considered ERP-system the following main functional blocks are realized:

- the supply management block monitors inventory, adjusts stock balances, conducts inventory, plans the need for materials, and determines the volume of orders that can be realized at a certain point in time;

- the production management block determines the amount of inventory that is used by the production activity; peculiarities of the production technology; labor management, quality management of the products produced;

- the sales management block determines the schedule of sales, the issuance of sales orders;

- the block of financial results management determines the financial result from the main activity, the income from sales, based on invoices, settlements with clients are made;

- the block of finance promptly generates information on the current system of taxation, settlements with the budget, cash flow, etc.

This structure, in our opinion, allows effective control of business processes by creating an integrated management system and achieving coherence between organizational units; makes it possible to integrate accounting, tax and management accounting, as well as the formation of financial and management reporting; promotes effective, timely management decisions in accordance with changes in market conditions; increases the efficiency of the organization employees. 


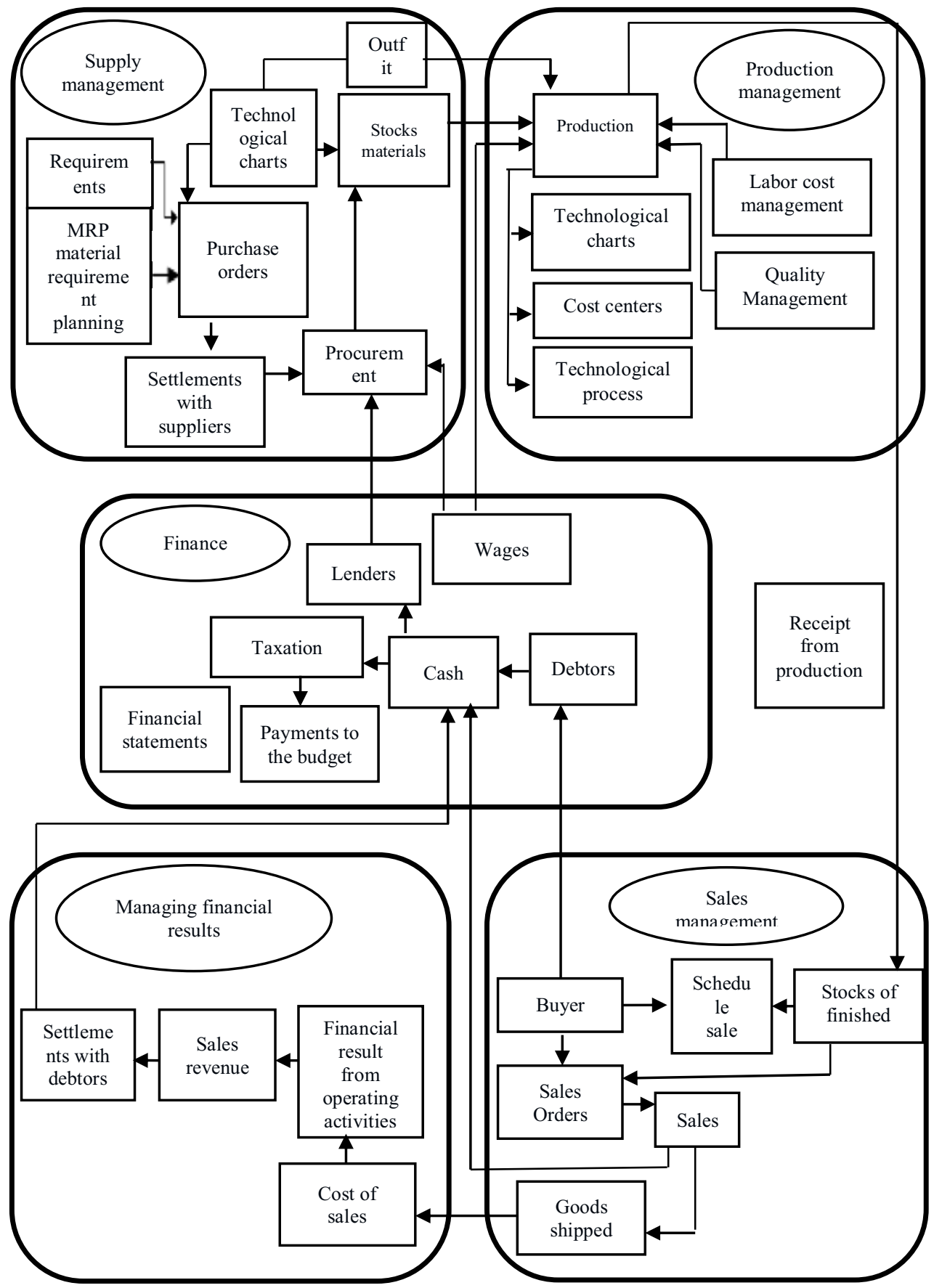

Fig. 3. Structure of ERP-system of the organization.

\section{Conclusions}

In the course of the research the organizational aspects were studied and the directions of improvement of methodological support of internal control of production costs and costing 
of products were proposed.

As a result of the internal control the inspector formulates conclusions and recommendations on elimination of the revealed deficiencies in the production costs accounting; recommends the management of the enterprise to introduce more progressive methods of cost accounting with the purpose of development of the information-analytical support of the cost management system of the enterprise.

It is recommended to use developed working documents of internal control as one of the tools of internal control. These documents allow:

- carry out effective planning of internal control;

- evaluate the effectiveness of internal control and accounting systems,

- systematize information received in the process of checking the primary accounting and observing norms of material resources consumption in production;

- summarize the results of inspection and reflection of violations and errors detected in the course of internal control.

Based on the proposed working documents, the controller can establish the units in which the greatest number of violations are observed. He also has the opportunity to confirm the reliability of information, to determine the points that should be reflected in the controller's report.

In addition, the organization of ERP-system is considered in sufficient detail. In our opinion, this structure allows to control effectively the business processes by creation of integrated control system and achievement of consistency between divisions of organization; gives possibility for integration of accounting, tax and management accounting, as well as formation of financial and management statements; promotes acceptance of effective, timely administrative decisions according to changes of market conditions; raises efficiency of work of employees of organization.

\section{References}

1. Y. Li, X. Li, E. Xiang, H.G. Djajadikerta, Journal of Contemporary Accounting \& Economics 16, 100210 (2020) https://doi.org/10.1016/j.jcae.2020.100210

2. G. Klychova, A. Klychova, A. Zakirova et al, E3S Web of Conferences 110, 02072 (2019) doi.org/10.1051/e3sconf/201911002072

3. H. Chen, D. Yang, J.H. Zhang, H. Zhou, Journal of Corporate Finance 64, 101695 (2020) https://doi.org/10.1016/j.jcorpfin.2020.101695

4. S.M. Saad, R. Bahadori, H. Jafarnejad, M.F. Putra, Procedia Computer Science 180, 618-627 (2021) https://doi.org/10.1016/j.procs.2021.01.284

5. G.S. Klychova, B.G. Ziganshin, A.R. Zakirova et al, Journal of Engineering and Applied Sciences 12, 4958-4965 (2017) DOI: 10.3923/jeasci.2017.4958.4965

6. J. Hu, Y.-Ch. Weng, F. Wang, Borsa Istanbul Review 24 (2020) https://doi.org/10.1016/j.bir.2020.12.006

7. Ch. Windmark, C. Andersson, Procedia Manufacturing 25, 231-238 (2018) https://doi.org/10.1016/j.promfg.2018.06.078

8. F. Duffner, L. Mauler, M. Wentker et al, International Journal of Production Economics 232, 107982 (2021) https://doi.org/10.1016/j.ijpe.2020.107982

9. V. De Leijster, R.W. Verburg, M.J. Santos et al, Agricultural Systems 183, 102878 (2020) https://doi.org/10.1016/j.agsy.2020.102878

10. G. Klychova, A. Zakirova, R. Mannapova et al, E3S Web of Conferences 110, 02075 (2019) doi.org/10.1051/e3sconf/201911002075 
11. M. Roussy, Critical Perspectives on Accounting 24, 550-571 (2013) https://doi.org/10.1016/j.cpa.2013.08.004

12. A. Zakirova, G. Klychova, R. Nurieva et al, Advances in Intelligent Systems and Computing, Advances in Intelligent Systems and Computing 1259 AISC, 98-123 (2021) https://doi.org/10.1007/978-3-030-57453-6_10

13. M. Hanskamp-Sebregts, P.B. Robben, H. Wollersheim, M. Zegers, Health Policy 124, 216-223 (2020) https://doi.org/10.1016/j.healthpol.2019.11.013

14. Sh.-I. Chang, L.-M. Chang, J.-C. Liao, Information \& Management 57, 103335 (2020) https://doi.org/10.1016/j.im.2020.103335

15. G.S. Klychova, A.R. Zakirova, E.R. Kamilova, International Business Management 10, 5254-5260 (2016)

16. K. Chalmers, D. Hay, H. Khlif, Journal of Accounting Literature 42, 80-103 (2019) https://doi.org/10.1016/j.acclit.2018.03.002

17. H. Li, J. Dai, T. Gershberg, M.A. Vasarhely, International Journal of Accounting Information Systems 28, 59-76 (2018) https://doi.org/10.1016/j.accinf.2017.12.005

18. G. Klychova, A. Zakirova, Sh. Khusainov, et al, E3S Web of Conferences 164, 10008 (2020) https://doi.org/10.1051/e3sconf/202015704022

19. Y.-T. Chang, H. Chen, R.K. Cheng, W. Chi, Journal of Contemporary Accounting \& Economics 15, 1-19 (2019) https://doi.org/10.1016/j.jcae.2018.11.002

20. P. Lebedev, Procedia - Social and Behavioral Sciences 213, 293-298 (2015) doi.org/10.1016/j.sbspro.2015.11.540

21. Z. Papulova, A. Gazova, Procedia Economics and Finance 39, $571-579$ (2016) https://doi.org/10.1016/S2212-5671(16)30301-X

22. A. Zakirova, G. Klychova, K. Mukhamedzyanov, et al, Advances in Intelligent Systems and Computing 1258 AISC, 687-707 (2021) https://doi.org/10.1007/978-3030-57450-5_59

23. D.B. Bryan, Advances in Accounting 36, 11-26 (2017) https://doi.org/10.1016/j.adiac.2016.09.005

24. A. Zakirova, G. Klychova, G. Ostaev et al, E3S Web of Conferences 164, 10008 (2020) https://doi.org/10.1051/e3sconf/202016410008

25. Th.D. Dowdell, D.N. Herda, M.A. Notbohm, Research in Accounting Regulation 26, 104-109 (2014) https://doi.org/10.1016/j.racreg.2014.02.011

26. H. Shen, H. Xiong, Sh. Zheng, F. Hou, Economic Modelling In press, corrected proof (2020) https://doi.org/10.1016/j.econmod.2020.03.011

27. P. Rikhardsson, O. Yigitbasioglu, International Journal of Accounting Information Systems 29, 37-58 (2018) doi.org/10.1016/j.accinf.2018.03.001

28. B. Bui, Ch. de Villiers, The British Accounting Review 49, 4-24 (2017) doi.org/10.1016/j.bar.2016.10.006

29. N.V. Syreyshchikova, D.Yu. Pimenov, T. Mikolajczyk, L. Moldovan, Procedia Manufacturing 46, 525-532 (2020) https://doi.org/10.1016/j.promfg.2020.03.075

30. A. Amado, F.P. Belfo, Procedia Computer Science 181, 580-588 (2021) https://doi.org/10.1016/j.procs.2021.01.205

31. L. Anaya, Procedia Computer Science 164, 33-38 (2019) https://doi.org/10.1016/j.procs.2019.12.151

32. O. Alaskari, R. Pinedo-Cuenca, M.M. Ahmad, Procedia Manufacturing 38, 69-75 (2019) https://doi.org/10.1016/j.promfg.2020.01.009 
33. J.K. Nwankpa, Computers in Human Behavior 45, 335-344 (2015) https://doi.org/10.1016/j.chb.2014.12.019 